\title{
Vitamin E Ameliorates the Mineralo-Oxidative Stress of Sucking Lice Infestation in Indian Water Buffalo
}

\author{
E. Madhesh ${ }^{1} *$, Umesh Dimri ${ }^{1}$, Y. Ajith ${ }^{1}$, S. Shanmuganathan ${ }^{2}$, \\ P. Sivasankar ${ }^{3}$, R. Karthikeyan ${ }^{4}$, Alok Kumar Choudhary ${ }^{1}$ and K. Kavitha ${ }^{1}$
}

${ }^{1}$ Division of Medicine, ${ }^{2}$ Division of Virology, ${ }^{3}$ Division of Microbiology, ${ }^{4}$ Division of Biochemistry, ICAR-Indian Veterinary Research Institute, Izatnagar, UP, India-243122

*Corresponding author

\begin{tabular}{|c|}
\hline Keywords \\
\hline $\begin{array}{l}\text { Vitamin E, } \\
\text { Bubaline } \\
\text { pediculosis, } \\
\text { Oxidative stress, } \\
\text { Mineral balance, N- }- \\
\text { acetyl cysteine }\end{array}$ \\
\hline Article Info \\
\hline $\begin{array}{l}\text { Accepted: } \\
\text { 12 June } 2019 \\
\text { Available Online: } \\
10 \text { July } 2019\end{array}$ \\
\hline
\end{tabular}

\section{Introduction} the host system.
Buffaloes considered as "black gold of India";

because buffaloes provide high quality

\section{A B S T R A C T}

Bubaline pediculosis is a common and economically important ectoparasitic condition caused by sucking lice, Haematopinus tuberculatus. This condition in buffalo is characterized by anemia, mineral imbalance, and loss of production performance but its pathobiology is explored less. Aim of the present study was to explore the mineralooxidaive pathobiology of bubaline pediculosis and its amelioration using the two antioxidants as an adjunct therapeutic modality ( $\mathrm{N}$ - acetyl cysteine and Vitamin E). Twenty four buffaloes, severely infested with sucking lice (mean total lice count more than 100) were divided into three groups (Group I, II and III) with eight animals per group; another eight animals (Group IV) free from any clinical abnormalities and ectoparasitism were included as healthy control. Lice infested animals (Group I, II and III) animals were given ivermectin therapy ( $200 \mu \mathrm{g} / \mathrm{kg}$ body weight SC single dose); additionally, group II and group III animals were orally treated with $\mathrm{N}$-acetyl cysteine $(12 \mathrm{mg} / \mathrm{kg}$ body weight $)$ and vitamin $\mathrm{E}$ (Tocopheryl acetate $4000 \mathrm{mg}$ per animal), respectively, once daily for 14 days. The haematological parameters (TEC, Hb, TLC and DLC), oxidant-antioxidant profile (TAC, LPO, GSH, and SOD) and mineral profile (Zinc, Iron, Magnesium, and Copper) were studied on before therapy (Day 0) and post therapy (Day 28). Bubaline pediculosis revealed severe oxidative stress and mineral imbalance along with remarkable anaemia and leukocytosis. Vitamin E given animals demonstrated better recovery from the mineralo-oxidative pathology of bubaline pediculosis and approached post therapeutic normalcy. Vitamin E as an adjunct therapy along with ivermectin alleviated the pathobiological damages in the host system and speed up the clinical recovery, whereas, Nacetyl cysteine was less effective in quenching the mineralo-oxidative response. Future studies on antioxidants therapy may target the influence of mineralo-oxidative response in

protein, fat rich milk, serve as a source of employment and livelihoods to millions of landless, marginal, and small farmers (Syed Mohmad and Manmohan Singh, 2017). 
Ectoparasitism adversely affects the welfare and production performance farm animals. Worldwide buffaloes were commonly infested with sucking lice, Haematopinus tuberculatus especially during the winter season can affect cattle also (Bastianetto and Leite, 2005; Egri, 2019; Mamun et al., 2010). Lice infestation in the animal was favored by the risk factors like lack of hygiene, low health status, low temperature-humid weather condition (Taylor et al., 2016). Sucking lice are sebaceous secretion feeders and bloodsuckers, which are less movable and remain tightly attached to the skin of host for a prolonged time. Lice induce hypersensitivity hence, severe H.tuberculatus infestations can result in varying levels of scratching, self-excoriation, alopecia, and papulo - crustous dermatitis (Chaudhry, 1978; Egri, 2019; Taylor et al., 2016). Recent findings revealed that inflammation and reactive oxygen species (ROS) induced tissue damage to play an important role in ectoparasitism induced deprivation of host health (Dimri et al., 2010).

Oxidative stress is defined as an imbalance between the production of the oxidants or free radicals and the ability of the body to quenching of their harmful effects through anti-oxidant defense system. The free radicals readily indices oxidative damage to various biomolecules including proteins, lipoprotein, lipids, and DNA and cause a disturbance in normal cellular signaling pathways and homeostasis (Farber, 1994; Kaur et al., 2006; Lykkesfeldt and Svendsen, 2007). Even, ectoparasiticides like cypermethrin, deltamethrin, and flumethrin usage in rats induce a significant oxidative stress (Dubey et al., 2013; Ince et al., 2013; Kanbur et al., 2010). The biomodulators use in the therapeutic management of various diseases is getting universal acceptance because of their vast scope in amelioration of a wide range of diseases conditions by altering the oxidative status. Generally, antioxidants are reducing agents belonging to the class such as thiols, ascorbates and polyphenols that can neutralize ROS and thereby inhibits the oxidation of other biomolecules. The recent finding suggests that antioxidants play a role in immunomodulation (Ajith et al., 2017). NAcetyl Cysteine (NAC) has been used for the treatment of acute and chronic bronchitis as a mucolytic agent for many years and is an antidote for acetaminophen poisoning. Fatsoluble vitamin $\mathrm{E}$ has an antioxidant property through which it can protect the polyunsaturated fatty acids (PUFAs) of the cell membrane from biological oxidation, regulate the production of reactive oxygen species (ROS) and modulate the signal transduction (Lee and Han, 2018).

Previous studies revealed that Vitamin E and $\mathrm{N}$-acetyl cysteine have good antioxidant with immunomodulatory properties (Dekhuijzen, 2004; Lee and Han, 2018). However, studies on the evaluation of these compounds in the management of mineralo-oxidative damage in bubaline pediculosis are not available. Hence, the focus of the current study was to examine the antioxidant potential of Vitamin $\mathrm{E}$ and $\mathrm{N}$ acetylcysteine in the management of pathobiology of bubaline pediculosis.

\section{Materials and Methods}

\section{Experimental design}

A total of twenty four Indian water buffaloes with "Severe" (cumulative count more than 100) sucking lice infestation were divided into three groups and another eight apparently healthy buffaloes without any parasitic infestation belonging to the 2-6 years age group was kept as healthy control. The severity of sucking lice infestation was carried out by summing of lice counted from different predilection sites; A-cheek $(5 \times 10 \mathrm{~cm}$ area), ear (5×10 cm area), C-neck and dewlap 
$(10 \times 20 \mathrm{~cm}$ area), D-withers $(10 \times 10 \mathrm{~cm}$ area $)$, E-foreleg $(10 \times 10 \mathrm{~cm}$ area $)$, F-back $(10 \times 10 \mathrm{~cm}$ area), G-hind leg $(10 \times 10 \mathrm{~cm}$ area), H-tail head and perineum $(10 \times 10 \mathrm{~cm}$ area $)$ using standard counting technique (Holdsworth et al., 2006; Veneziano et al., 2013, 2003). The Haematopinus tuberculatus infested buffaloes (Soulsby, 1982) were allotted three treatment plan; group I (Ivermectin injection @ 200 $\mu \mathrm{g} / \mathrm{kg}$ SC single dose), group II (Ivermectin injection@200 $\mu \mathrm{g} / \mathrm{kg} \mathrm{SC}$ single dose and Nacetyl cysteine @ $12 \mathrm{mg} / \mathrm{kg}$ SID PO for 14 days) and group III (Ivermectin injection @ $200 \mu \mathrm{g} / \mathrm{kg}$ SC single dose and Vitamin E 4000 mg per animal SID PO for 14 days). The remaining eight healthy animals without any parasitic infestation served as healthy control (group IV). Commercial preparations of Ivermectin (Hitek® injection, $1 \% \mathrm{w} / \mathrm{v}$; Virbac, India), Vitamin E (Evion ${ }^{\circledR}$ capsule, $400 \mathrm{mg}$; Merck, India) $\mathrm{N}$-acetyl cysteine (Fluimucil® Tablet, 600 mg; Elder Pharma, India) were used. WAAVP guidelines for evaluation of the ectoparasiticide efficacy was used for clinical evaluation of the different treatment plan (Holdsworth et al., 2006) and was assessed by calculating reduction percentage and assessment of mineralooxidative status (Veneziano et al., 2013).

\section{Sample collection and processing}

Animals were evaluated for changes in haematological, oxidant-antioxidant and mineral profile on before the start of therapy (day 0) and post therapy (day 28) of the experiment. Blood samples $(12 \mathrm{~mL})$ were collected by external jugular venipuncture in sterile EDTA and heparin coated vials.

Serum samples were collected in sterile vials and stored in a deep freezer for the estimation of mineral profile. About two milliliter of blood collected in sterile EDTA coated vials were utilized for haematological analysis. For estimation of oxidative stress parameters 6
$\mathrm{mL}$ of blood collected in heparin coated vial was utilized.

Estimation of catalase (CAT), lipid peroxidation (LPO), superoxide dismutase (SOD) were carried out in the hemolysate obtained from the $6 \mathrm{~mL}$ of the heparinized blood sample and whereas, reduced glutathione (GSH) estimation was carried out in RBC suspension obtained from the above blood sample. The cyanohemoglobin method described by Tentori and Salvati, (1981) was used for estimation of hemolysate haemoglobin concentration.

\section{Evaluation of oxidant and anti-oxidant profile}

The lipid peroxidation (LPO) levels were estimated as per the method described by Placer et al., (1966). DTNB method of Prins and Loos was used for the estimation of reduced glutathione (GSH) concentration in RBCs (Prins and Loos, 1969).

Estimation of superoxide dismutase (SOD) activity was carried out as per the method described by Madesh and Balasubramanian (1998). The method described by Aebi (1974) was used for estimation of Catalase (CAT) activity. Estimation of serum Total antioxidant capacity was carried out as per the manufacturer's instruction using Total Antioxidant Capacity (TAC) assay kit (Sigma-Aldrich, USA) (Miller and RiceEvans, 1997).

\section{Evaluation of hematological profile}

The method decribed by (Berman, 1919) was used for the estimation of haemoglobin concentration $(\mathrm{gm} / \mathrm{dl})$. Haematological parameters like TLC, TEC, and DLC were estimated as per the method described by (Schalm and Jain, 1986). 


\section{Statistical analysis}

The data were analyzed by two-way ANOVA with Tukey's post hoc test using IBM SPSS statistics package version 25.0 (Snecdecor and Cochran, 1994). The values were expressed as mean \pm S.E.

\section{Results and Discussion}

The mean lice count in different body regions for different treatment groups and healthy control on day 0 and day 28 is depicted in table 1. The sucking lice of buffalo were mostly concentrated on withers, back and neck and dewlap regions, followed by cheek, foreleg, hind leg, tail head and perineum, which is not available for animal's selfgrooming. The lice infestation was clinically manifested as dermatological lesions related to weakness, hyper-sensitivity reaction, pruritus, alopecia, and seborrhea. However, lice infestation was reduced significantly in all three treated groups on day 28, group III showed better clinical improvement of clinical signs and skin condition.

The hematological profile of sucking lice infested buffaloes had significant $(\mathrm{p}<0.05)$ anaemia and leukocytosis with neutrophilia, lymphocytopenia, eosinophilia (Table 2). Remarkable improvement of haematological profile (Hb, TEC, TLC, and DLC) by day 28 was observed in all three treatment groups, but, group III values were similar to the healthy control group. Lice infested animals showed significant oxidative stress, with significantly elevated oxidant (LPO) levels and decreased serum TAC, SOD, reduced GSH level, and CAT (Table 3). Moreover, cell membrane lipids oxidative damage biomarker malondialdehyde was significantly $(\mathrm{p}<0.05)$ reduced in the three treatment groups on day 28 and group II and group III of the treated animals value were closely comparable to the healthy control group. All the treated groups revealed significant improvement of their antioxidant defense statuses like serum TAC, SOD activity, CAT activity and reduced glutathione on day 28 , but, the group II and group III showed remarkable improvement closer to the healthy control group.

The mineral profile of lice infested animal revealed a significantly $(\mathrm{p}<0.05)$ decreased serum iron, zinc, magnesium (Table 4). However, serum copper levels did not differ significantly between infested and healthy control animals and all the three treatments did not alter serum copper levels much. Group 11 and group III of the treated animals iron, zinc, magnesium levels were improved on day 28 and values were almost similar to the healthy control.

In the present study, sucking lice infested buffaloes were found to have marked oxidative stress, severe mineral imbalance, iron deficiency anaemia, leukocytosis with neutrophilia, eosinophilia and lymphocytopenia. Similar mineral imbalance, oxidative stress and hematological changes were observed in other ectoparasitism like ovine pediculosis (Dede et al., 2002), caprine pediculosis (Ajith et al., 2017), bubaline pediculosis(El-Moghazy, 2011), demodicosis in dogs (Dimri et al., 2008), psoroptic mange infection in sheep (Aktas et al., 2017), sarcoptic mange in goats (De and Dey, 2010), dogs (Behera et al., 2011; Singh and Dimri, 2013) and buffaloes (Dimri et al., 2007). Accruing evidence from recent studies is promising the potential use of antioxidants in prophylactic and therapeutic management of the infectious disease. The ameliorative potential of the antioxidants in management of parasitic disease is increasing dramatically, Vitamin C in caprine pediculosis (Ajith et al., 2019), Vitamin E-Selenium for sarcoptic mange in canines (Behera et al., 2011; Singh and Dimri, 2013), Vitamin ADEH for 
psoroptic in rabbit (Singh et al., 2012) and herbal essential oils for sarcoptic mange infestation in sheep (Dimri and Sharma, 2004).

$\mathrm{N}$-Acetyl cysteine (NAC), a mucolytic agent, has been used for the treatment of acute and chronic bronchitis in patients for many years and also used as an antidote for acetaminophen toxicity. NAC has been used as a possible chemo-preventive agent is due to its anti-oxidative or detoxifying properties (De Vries and De Flora, 1993). NAC exhibits both direct and indirect antioxidant properties; acts directly by interaction with free electrophilic thiol groups of ROS (Dekhuijzen, 2004). NAC acts indirectly by increasing the intracellular concentrations of cysteine, GSH and oxidant species scavenging. NAC administered orally for seven days in milking goats had quenched the effects of oxidative stress (Jóźwik et al., 2010). Vitamin E, the part of the chainbreaking antioxidant system, scavenges the free radicals and prevents the oxidation of membrane lipids (McDowell, 2000). Vitamin E prevents the peroxidation of phospholipids by acting as the first line of defense against membrane peroxidation. In the present study Vitamin E treated animals had a marked improvement of antioxidant and mineral status compared to $\mathrm{N}$-acetyl cysteine treated animals might be due to NAC mediated activation of $\mathrm{Th} 2$ response in lice infestation (Ajith et al., 2019). Vitamin E is an effective antioxidant with anti-inflammatory property might help in improvement of general body condition, mineral balance and oxidative stress in sucking lice infested buffaloes (Tahan et al., 2011).

Table.1 Mean lice count in different body regions of sucking lice (Haematopinus tuberculatus) infested treatment groups on day 0 and day 28

\begin{tabular}{|c|c|c|c|c|c|c|c|c|}
\hline \multirow[t]{2}{*}{ Body Region } & \multicolumn{2}{|c|}{ Group I(n=8) } & \multicolumn{2}{|c|}{ Group II $(n=8)$} & \multicolumn{2}{|c|}{ Group III $(n=8)$} & \multicolumn{2}{|c|}{ Group IV (n=8) } \\
\hline & Day 0 & Day 28 & Day 0 & Day 28 & Day 0 & $\begin{array}{c}\text { Day } \\
28\end{array}$ & Day 0 & Day 28 \\
\hline Cheek & 10.86 & 0.25 & 10.78 & 0.33 & 12.58 & 0 & 0 & 0 \\
\hline Ear & 2.27 & 0 & 2.47 & 0 & 2.17 & 0 & 0 & 0 \\
\hline Neck and dewlap & 30.52 & 0.78 & 30.82 & 0.54 & 30.42 & 0 & 0 & 0 \\
\hline Withers & 91.68 & 1.63 & 92.27 & 1.43 & 96.67 & 0 & 0 & 0 \\
\hline Foreleg & 8.18 & 0 & 8.64 & 0 & 8.08 & 0 & 0 & 0 \\
\hline Back & 25.22 & 0.53 & 24.78 & 0.45 & 25.58 & 0 & 0 & 0 \\
\hline Hind leg & 2.28 & 0 & 2.58 & 0 & 2.08 & 0 & 0 & 0 \\
\hline $\begin{array}{l}\text { Tail head and } \\
\text { perineum }\end{array}$ & 4.77 & 0 & 6.12 & 0 & 4.17 & 0 & 0 & 0 \\
\hline $\begin{array}{l}\text { Cumulative count } \\
\text { (Mean) }\end{array}$ & 175.78 & 3.19 & 178.46 & 2.75 & 181.75 & 0 & 0 & 0 \\
\hline $\begin{array}{c}\text { Reduction } \\
\text { percentage* }\end{array}$ & \multicolumn{2}{|c|}{98.18} & \multicolumn{2}{|c|}{99.01} & \multicolumn{2}{|c|}{100} & \multicolumn{2}{|c|}{-} \\
\hline
\end{tabular}


Table.2 Haematological profile of lice infested goats (Mean \pm SE)

\begin{tabular}{|c|c|c|}
\hline Parameter & Day 0 & Day 28 \\
\hline \multicolumn{3}{|l|}{ Hemoglobin concentration (gm/dl) } \\
\hline Group I $(\mathrm{n}=\mathbf{8})$ & $9.02 \pm 0.28^{\mathrm{Bb}}$ & $12.22 \pm 0.23^{\mathrm{Ca}}$ \\
\hline Group II $(n=8)$ & $9.05 \pm 0.26^{\mathrm{Bb}}$ & $13.52 \pm 0.26^{\mathrm{Ba}}$ \\
\hline Group III $(\mathbf{n}=\mathbf{8})$ & $9.07 \pm 0.25^{\mathrm{Bb}}$ & $15.68 \pm 0.24^{\mathrm{Aa}}$ \\
\hline Group IV (n=8) & $15.65 \pm 0.35^{\mathrm{Aa}}$ & $15.72 \pm 0.32^{\mathrm{Aa}}$ \\
\hline \multicolumn{3}{|c|}{ Total Erythrocyte count-TEC (million cells/ $\mu \mathrm{L}$ ) } \\
\hline Group I $(n=8)$ & $3.52 \pm 0.24^{\mathrm{Bb}}$ & $4.46 \pm 0.12^{\mathrm{Ca}}$ \\
\hline Group II (n=8) & $3.63 \pm 0.23^{\mathrm{Bb}}$ & $6.52 \pm 0.13^{\mathrm{Ba}}$ \\
\hline Group III $(n=8)$ & $3.56 \pm 0.18^{\mathrm{Bb}}$ & $6.58 \pm 0.15^{\mathrm{Ba}}$ \\
\hline Group IV $(n=8)$ & $6.59 \pm 0.14^{\mathrm{Aa}}$ & $6.60 \pm 0.12^{\mathrm{Aa}}$ \\
\hline \multicolumn{3}{|c|}{ Total Leukocyte count-TLC (Thousand cells/ $\mu \mathrm{L}$ ) } \\
\hline Group I $(\mathbf{n}=8)$ & $16.08 \pm 0.25^{\mathrm{Ab}}$ & $14.63 \pm 0.26 \mathrm{Aa}$ \\
\hline Group II (n=8) & $16.04 \pm 0.22^{\mathrm{Ab}}$ & $12.56 \pm 0.24^{\mathrm{Ba}}$ \\
\hline Group III $(n=8)$ & $16.07 \pm 0.23^{\mathrm{Ab}}$ & $12.25 \pm 0.22^{\mathrm{Ba}}$ \\
\hline Group IV $(n=8)$ & $11.58 \pm 0.22^{\mathrm{Ba}}$ & $11.56 \pm 0.23^{\mathrm{Ca}}$ \\
\hline \multicolumn{3}{|c|}{ Differential Leukocyte Count-DLC (\%) } \\
\hline \multicolumn{3}{|l|}{ Neutrophil (\%) } \\
\hline Group I $(n=8)$ & $45.43 \pm 0.52^{\mathrm{Ab}}$ & $42.43 \pm 0.53^{\mathrm{Aa}}$ \\
\hline Group II (n=8) & $44.73 \pm 0.52^{\mathrm{Ab}}$ & $40.24 \pm 0.46^{\mathrm{Ba}}$ \\
\hline Group III $(\mathrm{n}=8)$ & $45.43 \pm 0.52^{\mathrm{Ab}}$ & $38.07 \pm 0.55^{\mathrm{Ca}}$ \\
\hline Group IV $(n=8)$ & $37.58 \pm 0.38^{\mathrm{Ba}}$ & $37.78 \pm 0.36^{\mathrm{Ca}}$ \\
\hline \multicolumn{3}{|l|}{ Lymphocyte (\%) } \\
\hline Group I $(n=8)$ & $42.11 \pm 0.68^{\mathrm{Bb}}$ & $52.58 \pm 0.45^{\mathrm{Ca}}$ \\
\hline Group II (n=8) & $42.28 \pm 0.62^{\mathrm{Bb}}$ & $55.52 \pm 0.38^{\mathrm{Ba}}$ \\
\hline Group III $(\mathrm{n}=\mathbf{8})$ & $42.18 \pm 0.63^{\mathrm{Bb}}$ & $58.54 \pm 0.42^{\mathrm{Aa}}$ \\
\hline Group IV $(n=8)$ & $59.13 \pm 1.03^{\mathrm{Aa}}$ & $59.13 \pm 1.03^{\mathrm{Aa}}$ \\
\hline \multicolumn{3}{|l|}{ Eosinophil (\%) } \\
\hline Group I (n=8) & $6.08 \pm 0.42^{\mathrm{Aa}}$ & $4.58 \pm 0.40^{\mathrm{Ab}}$ \\
\hline Group II (n=8) & $6.08 \pm 0.42^{\mathrm{Aa}}$ & $2.35 \pm 0.38^{\mathrm{Bb}}$ \\
\hline Group III (n=8) & $6.08 \pm 0.42^{\mathrm{Aa}}$ & $1.56 \pm 0.42^{\mathrm{Cb}}$ \\
\hline Group IV $(n=8)$ & $1.42 \pm 0.19^{\mathrm{Ba}}$ & $1.44 \pm 0.22^{\mathrm{Ca}}$ \\
\hline \multicolumn{3}{|l|}{ Monocyte (\%) } \\
\hline Group I (n=8) & $2.18 \pm 0.22^{\mathrm{Aa}}$ & $1.42 \pm 0.18^{\mathrm{Ab}}$ \\
\hline Group II (n=8) & $2.15 \pm 0.23^{\mathrm{Aa}}$ & $1.32 \pm 0.12^{\mathrm{Bb}}$ \\
\hline Group III $(\mathrm{n}=8)$ & $2.16 \pm 0.20^{\mathrm{Aa}}$ & $1.26 \pm 0.16^{\mathrm{Ca}}$ \\
\hline Group IV $(n=8)$ & $1.25 \pm 0.13^{\mathrm{Ba}}$ & $1.25 \pm 0.15^{\mathrm{Ca}}$ \\
\hline \multicolumn{3}{|l|}{ Basophil (\%) } \\
\hline Group I (n=8) & $1.08 \pm 0.15^{\mathrm{Aa}}$ & $0.92 \pm 0.18^{\mathrm{Aa}}$ \\
\hline Group II (n=8) & $0.92 \pm 0.15^{\mathrm{Aa}}$ & $0.83 \pm 0.21^{\mathrm{Aa}}$ \\
\hline Group III (n=8) & $0.96 \pm 0.13^{\mathrm{Aa}}$ & $0.67 \pm 0.14^{\mathrm{Aa}}$ \\
\hline Group IV (n=8) & $0.7 \pm 0.15^{\mathrm{Aa}}$ & $0.7 \pm 0.19^{\mathrm{Aa}}$ \\
\hline
\end{tabular}

Values with different superscripts A, B, C, D differ significantly $(\mathrm{p}<0.05)$ in the same column

Values with different superscripts $a, b$ differ significantly $(p<0.05)$ in the same row 
Table.3 Variation in oxidant-antioxidant profile of treatment groups on day 0 and day 28 $(\mathrm{Mean} \pm \mathrm{SE})$

\begin{tabular}{|c|c|c|}
\hline Parameter & Day 0 & Day 28 \\
\hline \multicolumn{3}{|c|}{ Lipid per oxidation-LPO (nM MDA/mg Hb) } \\
\hline Group I (n=8) & $8.26 \pm 0.12^{\mathrm{Aa}}$ & $7.58 \pm 0.16^{\mathrm{Ab}}$ \\
\hline Group II (n=8) & $8.34 \pm 0.18^{\mathrm{Aa}}$ & $6.62 \pm 0.15^{\mathrm{Bb}}$ \\
\hline Group III (n=8) & $8.56 \pm 0.16^{\mathrm{Aa}}$ & $6.52 \pm 0.13^{\mathrm{Bb}}$ \\
\hline Group IV $(\mathbf{n}=8)$ & $6.36 \pm 0.18^{\mathrm{Ba}}$ & $6.42 \pm 0.15^{\mathrm{Ba}}$ \\
\hline \multicolumn{3}{|c|}{ Reduced glutathione-GSH $(\mu \mathrm{Mol} / \mathrm{ml}$ of packed RBC) } \\
\hline Group I (n=8) & $0.63 \pm 0.04^{\mathrm{Bb}}$ & $0.68 \pm 0.02^{\mathrm{Ca}}$ \\
\hline Group II (n=8) & $0.65 \pm 0.03^{\mathrm{Bb}}$ & $0.78 \pm 0.04^{\mathrm{Ba}}$ \\
\hline Group III (n=8) & $0.64 \pm 0.02^{\mathrm{Bb}}$ & $0.81 \pm 0.03^{\mathrm{Ba}}$ \\
\hline Group IV (n=8) & $0.84 \pm 0.03^{\mathrm{Aa}}$ & $0.85 \pm 0.04^{\mathrm{Aa}}$ \\
\hline \multicolumn{3}{|c|}{ Super Oxide Dismutase-SOD ( $\mu \mathrm{mol} / \mathrm{mg} \mathrm{Hb})$} \\
\hline Group I (n=8) & $8.06 \pm 0.25^{\mathrm{Bb}}$ & $9.28 \pm 0.18^{\mathrm{Ca}}$ \\
\hline Group II (n=8) & $8.07 \pm 0.26^{\mathrm{Bb}}$ & $9.68 \pm 0.24^{\mathrm{Ba}}$ \\
\hline Group III (n=8) & $8.08 \pm 0.27^{\mathrm{Bb}}$ & $9.75 \pm 0.25^{\mathrm{Ba}}$ \\
\hline Group IV $(n=8)$ & $10.22 \pm 0.16^{\mathrm{Aa}}$ & $10.19 \pm 0.14^{\mathrm{Az}_{\mathrm{Z}}}$ \\
\hline \multicolumn{3}{|c|}{ Catalase activity-CAT $\left(\mu \mathrm{mol} \mathrm{H}_{2} \mathrm{O}_{2}\right.$ decomposed/min/mg $\left.\mathrm{Hb}\right)$} \\
\hline Group I (n=8) & $4.69 \pm 0.12^{\mathrm{Bb}}$ & $6.12 \pm 0.12^{\mathrm{Ca}}$ \\
\hline Group II (n=8) & $4.73 \pm 0.15^{\mathrm{Bb}}$ & $6.75 \pm 0.14^{\mathrm{Ba}}$ \\
\hline Group III (n=8) & $4.75 \pm 0.14^{\mathrm{Bb}}$ & $6.79 \pm 0.14^{\mathrm{Ba}}$ \\
\hline Group IV (n=8) & $6.85 \pm 0.23^{\mathrm{Aa}}$ & $6.82 \pm 0.25^{\mathrm{Aa}}$ \\
\hline \multicolumn{3}{|c|}{ Total Antioxidant Capacity-TAC (mM/L of serum) } \\
\hline Group I $(n=8)$ & $0.80 \pm 0.23^{\mathrm{Bb}}$ & $1.25 \pm 0.17^{\mathrm{Ba}}$ \\
\hline Group II (n=8) & $0.81 \pm 0.22^{\mathrm{Bb}}$ & $1.73 \pm 0.13^{\mathrm{Aa}}$ \\
\hline Group III (n=8) & $0.82 \pm 0.26^{\mathrm{Bb}}$ & $1.76 \pm 0.15^{\mathrm{Aa}}$ \\
\hline Group IV (n=8) & $1.78 \pm 0.08^{\mathrm{Aa}}$ & $1.79 \pm 0.10^{\mathrm{Aa}}$ \\
\hline
\end{tabular}

Values with different superscripts A, B, C, D differ significantly $(\mathrm{p}<0.05)$ in the same Column Values with different superscripts a, b differ significantly $(\mathrm{p}<0.05)$ in the same row 
Table.4 Mineral profile of lice infested buffaloes (Mean \pm SE)

\begin{tabular}{|c|c|c|}
\hline Parameter & Day 0 & Day 28 \\
\hline \multicolumn{3}{|l|}{ Serum Iron $(\mu \mathrm{g} / \mathrm{dL})$} \\
\hline Group I (n=8) & $113.30 \pm 1.23^{\mathrm{Ba}}$ & $145.23 \pm 1.12^{\mathrm{Ca}}$ \\
\hline Group II (n=8) & $115.25 \pm 1.22^{\mathrm{Ba}}$ & $155.44 \pm 1.16^{\mathrm{Ba}}$ \\
\hline Group III (n=8) & $114.28 \pm 1.25^{\mathrm{Ba}}$ & $158.58 \pm 1.13^{\mathrm{Ba}}$ \\
\hline Group IV (n=8) & $158.09 \pm 2.30^{\mathrm{Aa}}$ & $160.09 \pm 2.35^{\mathrm{Aa}}$ \\
\hline \multicolumn{3}{|l|}{ Serum Zinc $(\mu \mathrm{g} / \mathrm{dL})$} \\
\hline Group I $(n=8)$ & $97.28 \pm 8.42^{\mathrm{Bb}}$ & $122.32 \pm 3.14^{\mathrm{Ca}}$ \\
\hline Group II (n=8) & $96.30 \pm 8.46^{\mathrm{Bb}}$ & $136.22 \pm 3.16^{\mathrm{Ba}}$ \\
\hline Group III (n=8) & $98.32 \pm 8.48^{\mathrm{Bb}}$ & $139.36 \pm 3.21^{\mathrm{Ba}}$ \\
\hline Group IV (n=8) & $143.52 \pm 1.61^{\mathrm{Aa}}$ & $143.48 \pm 1.53^{\mathrm{Aa}}$ \\
\hline \multicolumn{3}{|l|}{ Serum Copper $(\mu \mathrm{g} / \mathrm{dL})$} \\
\hline Group I (n=8) & $68.65 \pm 5.43^{\mathrm{Aa}}$ & $73.65 \pm 1.23^{\mathrm{Aa}}$ \\
\hline Group II (n=8) & $68.58 \pm 5.42^{\mathrm{Aa}}$ & $72.45 \pm 1.28^{\mathrm{Aa}}$ \\
\hline Group III (n=8) & $68.53 \pm 5.42^{\mathrm{Aa}}$ & $74.45 \pm 1.23^{\mathrm{Aa}}$ \\
\hline Group IV (n=8) & $75.33 \pm 1.28^{\mathrm{Aa}}$ & $75.38 \pm 1.23^{\mathrm{Aa}}$ \\
\hline \multicolumn{3}{|l|}{ Serum Magnesium (mEq/L) } \\
\hline Group I (n=8) & $0.52 \pm 0.03^{\mathrm{Bb}}$ & $1.45 \pm 0.06^{\mathrm{Ba}}$ \\
\hline Group II (n=8) & $0.54 \pm 0.02^{\mathrm{Bb}}$ & $1.63 \pm 0.05^{\mathrm{Aa}}$ \\
\hline Group III (n=8) & $0.52 \pm 0.05^{\mathrm{Bb}}$ & $1.65 \pm 0.03^{\mathrm{Aa}}$ \\
\hline Group IV (n=8) & $1.66 \pm 0.09^{\mathrm{Aa}}$ & $1.67 \pm 0.07^{\mathrm{Aa}}$ \\
\hline
\end{tabular}

Values with different superscripts A, B, C, D differ significantly $(\mathrm{p}<0.05)$ in the same column

Values with different superscripts $a, b$ differ significantly $(p<0.05)$ in the same row

The proper functioning of the antioxidant defense needs several trace minerals, thus mineral imbalance contributes to the development of oxidative stress. Magnesium act as an antioxidant by participating as a cofactor for several enzymes, maintaining the stability of cell membranes and mitigating the effects of oxidative stress (Morais et al., 2017). Magnesium deficiency enhances the generation of ROS, free radicals and increases the substrates available for radical oxidation (Zheltova et al., 2016). The normal functioning of the enzymes involved in antioxidant defense system requires zinc as a cofactor and zinc also protects cells by stabilization of cell membranes, inhibition of nicotinamide adenine dinucleotide phosphate oxidase (NADPH-Oxidase) enzyme and synthesis of metallothionein proteins that are effective in sequestration of ROS and reduction of hydroxyl radicals (Chasapis et al., 2012; Ruz et al., 2013).

Increased oxidative stress has been associated with magnesium and zinc deficiencies; magnesium deficiency increases ROS level and simultaneously decreasing the expression of antioxidant enzyme whereas zinc plays an indirect antioxidant role by serving as a structural cofactor and essential catalytic for superoxide dismutase and other enzymes (Eide, 2011). For $\mathrm{Cu}-\mathrm{Zn}$ superoxide dismutase, the antioxidant enzyme, both zinc and copper are act as essential components. 
Therefore, utilization or sequestration of $\mathrm{Zn}$ and $\mathrm{Cu}$ to neutralize the excessively produced ROS and the general poor condition of affected animals might be responsible for their lower level in the blood of pediculosis affected animals (Dede et al., 2002; Dimri et al., 2010). Anaemia in sucking lice infested buffaloes might have resulted from prolonged blood loss and iron deficiency. The loss of essential nutrients, iron deficiency and oxidative stress induced erythrocyte damage might have attributed to anaemia of the lice infested buffaloes. For iron deficiency anaemia development, oxidative stress plays a crucial role (Yoo et al., 2009).

In conclusion, ubaline pediculosis is associated with severe anaemia, oxidative stress, mineral imbalance and leukocytosis with neutrophilia, lymphocytopenia, and eosinophilia. N-Acetyl cysteine as an adjunct antioxidant is less effective than Vitamin $\mathrm{E}$ in reducing mineralo-oxidative pathology of bubaline pediculosis. Future studies on antioxidants therapy may target the influence of mineralo-oxidative response in the host system.

\section{Acknowledgements}

The authors sincerely thank SEED division, Department of Science and Technology, Ministry of Science and Technology, Government of India for funding this work under DST-SARTHI (Grant no. SEED/SARTHI/HP/19/2012) scheme. The authors are also thankful to Dr. Anil P. Joshi, Dr. Rakesh Kumar and Dr. Kiran Negi from Himalayan Environmental Studies and Conservation Organisation (HESCO), Dehradun.

\section{References}

Aebi, H., 1974. Catalase, in: Methods of Enzymatic Analysis. Elsevier, pp. 673-684.

Ajith, Y, Dimri, U., Singh, S.K., Gopalakrishnan,
A., Devi, G., Verma, M.R., Joshi, V., Alam, S., 2017. Lice induced immuno-oxidative wreckage of goats. Vet. Parasitol. 242, 2430.

Ajith, Y., Dimri, U., Dixit, S.K., Singh, S.K., Gopalakrishnan, A., Madhesh, E., Rajesh, J.B., Sangeetha, S.G., 2017. Immunomodulatory basis of antioxidant therapy and its future prospects: an appraisal. Inflammopharmacology 25, 487-498.

Ajith, Y., Dimri, U., Gopalakrishnan, A., Devi, G., Junaid, N., Madhesh, E., 2019. Host immunomodulation by ascorbic acid ameliorates oxidative stress in caprine pediculosis-A pilot study. Small Rumin. Res. 176, 65-69.

Aktas, M.S., Kandemir, F.M., Kirbas, A., Hanedan, B., Aydin, M.A., 2017. Evaluation of oxidative stress in sheep infected with Psoroptes ovis using total antioxidant capacity, total oxidant status, and malondialdehyde level. J. Vet. Res. 61, 197201.

Bastianetto, E., Leite, R.C., 2005. Control of the louse (Haematopinus tuberculatus) in herds of water buffalo (Bubalus bubalis) raised for milk and meat. Rev Bras Reprod Anim, Belo Horiz. 29, 118-121.

Behera, S.K., Dimri, U., Singh, S.K., Mohanta, R.K., 2011. The curative and antioxidative efficiency of ivermectin and ivermectin+ vitamin E-selenium treatment on canine Sarcoptes scabiei infestation. Vet. Res. Commun. 35, 237-244.

Berman, L., 1919. The determination of hemoglobin by the acid hematin method. Arch. Intern. Med. 24, 553-556.

Chasapis, C.T., Loutsidou, A.C., Spiliopoulou, C.A., Stefanidou, M.E., 2012. Zinc and human health: an update. Arch. Toxicol. 86, 521-534.

Chaudhry, N.I., 1978. Common disease problems in buffalo calves. Pak. J. Sci. 30, 120-126.

De Vries, N., De Flora, S., 1993. N- acetyl- 1- cysteine. J. Cell. Biochem. 53, 270-277.

De, U.K., Dey, S., 2010. Evaluation of organ function and oxidant/antioxidant status in goats with sarcoptic mange. Trop. Anim. Health Prod. 42, 1663-1668.

Dede, S., Deger, Y., Deger, S., 2002. Serum 
Copper, Zinc, and Calcium Concentrations in Lice-Infested Sheep. 274 Biol. Trace Elem. Res. 88, 87-90.

Dekhuijzen, P.N.R., 2004. Antioxidant properties of $\mathrm{N}$ - acetylcysteine: their relevance in relation to chronic obstructive pulmonary disease. Eur. Respir. J. 23, 629-636.

Dimri, U., Ranjan, R., Kumar, N., Sharma, M.C., Swarup, D., Sharma, B., Kataria, M., 2008. Changes in oxidative stress indices, zinc and copper concentrations in blood in Canine demodicosis. Vet. Parasitol. 154, 98-102.

Dimri, U., Ranjan, R., Singh, S.K., Sharma, M.C., Swarup, D., Dwivedi, P., Sharma, A.K., Kataria, M., 2007. Clinico-pathological and haemato-biochemical changes in buffaloes with sarcoptic mange. Indian J. Vet. Pathol. 31, 160-162.

Dimri, U., Sharma, M.C., 2004. Effects of Sarcoptic Mange and its Control with Oil of Cedrus deodara, Pongamia glabra, Jatropha curcas and Benzyl Benzoate, both with and without Ascorbic Acid on Growing Sheep: Epidemiology; Assessment of Clinical, Haematological, Cell- Mediated Humoral Immune Responses and Pathology. J. Vet. Med. Ser. A 51, 71-78.

Dimri, U., Sharma, M.C., Yamdagni, A., Ranjan, R., Zama, M.M.S., 2010. Psoroptic mange infestation increases oxidative stress and decreases antioxidant status in sheep. Vet. Parasitol. 168, 318-322.

Dubey, N., Khan, A.M., Raina, R., 2013. Subacute deltamethrin and fluoride toxicity induced hepatic oxidative stress and biochemical alterations in rats. Bull. Environ. Contam. Toxicol. 91, 334-338.

Egri, B., 2019. Louse Infestation of Ruminants, in: Bovine Science - A Key to Sustainable Development. IntechOpen, Rijeka, p. Ch. 6.

Eide, D.J., 2011. The oxidative stress of zinc deficiency. Metallomics 3, 1124-1129.

El-Moghazy, F.M., 2011. Effect of parasitic infestation on oxidant/antioxidant status in buffaloes. Middle East J. Sci. Res. 7, 585593.

Farber, J.L., 1994. Mechanisms of cell injury by activated oxygen species. Environ. Health Perspect. 102, 17-24.

Holdsworth, P.A., Vercruysse, J., Rehbein, S., Peter, R.J., Letonja, T., Green, P., 2006.
World Association for the Advancement of Veterinary Parasitology (W.A.A.V.P.) guidelines for evaluating the efficacy of ectoparasiticides against biting lice, sucking lice and sheep keds on ruminants. Vet. Parasitol. 136, 45-54.

Ince, S., Kucukkurt, I., Demirel, H.H., Turkmen, R., Zemheri, F., Akbel, E., 2013. The role of thymoquinone as antioxidant protection on oxidative stress induced by imidacloprid in male and female Swiss albino mice. Toxicol. Environ. Chem. 95, 318-329.

Jóźwik, A., Bagnicka, E., Strzałkowska, N., Śliwa-Jóźwik, A., Horbańczuk, K., Cooper, R.G., Pyzel, B., Krzyżewski, J., Świergiel, A.H., Horbańczuk, J.O., 2010. The oxidative status of milking goats after per os administration of $\mathrm{N}$-acetylcysteine. Anim. Sci. Pap. Reports 28, 143-152.

Kanbur, M., Eraslan, G., Sarica, Z.S., Altinordulu, Ş., 2010. The effects of Saw palmetto on flumethrin-induced lipid peroxidation in rats. Pestic. Biochem. Physiol. 97, 43-46.

Kaur, G., Alam, M.S., Jabbar, Z., Javed, K., Athar, M., 2006. Evaluation of antioxidant activity of Cassia siamea flowers. J. Ethnopharmacol. 108, 340-348.

Lee, G., Han, S., 2018. The Role of Vitamin E in Immunity. Nutrients 10, 1614.

Lykkesfeldt, J., Svendsen, O., 2007. Oxidants and antioxidants in disease: oxidative stress in farm animals. Vet. J. 173, 502-511.

Madesh, M., Balasubramanian, K.A., 1998. Microtiter plate assay for superoxide dismutase using MTT reduction by superoxide. Indian J. Biochem. Biophys. 35, 184-188.

Mamun, M.A.A., Begum, N., Shahadat, H.M., Mondal, M.M.H., 2010. Ectoparasites of buffaloes (Bubalus bubalis) in Kurigram district of Bangladesh. J. Bangladesh Agric. Univ. 8, 61-66.

McDowell, L.R., 2000. Vitamins in animal and human nutrition. $2^{\text {nd }}$ edn., Iowa State University Press, Ames, p.793.

Miller, N.J., Rice-Evans, C.A., 1997. Factors influencing the antioxidant activity determined by the ABTS $\bullet+$ radical cation assay. Free Radic. Res. 26, 195-199.

Morais, J.B.S., Severo, J.S., Santos, L.R. Dos, de Sousa Melo, S.R., de Oliveira Santos, R., de 
Oliveira, A.R.S., Cruz, K.J.C., do Nascimento Marreiro, D., 2017. Role of Magnesium in Oxidative Stress in Individuals with Obesity. Biol. Trace Elem. Res. 176, 20-26.

Placer, Z.A., Cushman, L.L., Johnson, B.C., 1966. Estimation of product of lipid peroxidation (malonyl dialdehyde) in biochemical systems. Anal. Biochem. 16, 359-364.

Prins, H.K., Loos, J.A., 1969. Glutathione, in: Biochemical Methods in Red Cell Genetics. Academic Press New York, pp. 115-137.

Ruz, M., Carrasco, F., Rojas, P., Codoceo, J., Inostroza, J., Basfi-Fer, K., Valencia, A., Vásquez, K., Galgani, J., Pérez, A., 2013. Zinc as a potential coadjuvant in therapy for type 2 diabetes. Food Nutr. Bull. 34, 215221.

Schalm, O.W., Jain, N.C., 1986. Schalm's veterinary haematology, $4^{\text {th }}$ edn., Lea and Febiger, Philadelphia, PA, p. 1221.

Singh, S.K., Dimri, U., 2013. Amelioration of sarcoptic mange-induced oxidative stress and apoptosis in dogs by using Calendula officinalis flower extracts. ISRN Oxidative Med. 2013.

Singh, S.K., Dimri, U., Sharma, M.C., Swarup, D., Kumar, M., Tiwary, R., 2012. Psoroptes cuniculi induced oxidative imbalance in rabbits and its alleviation by using vitamins $\mathrm{A}, \mathrm{D} 3, \mathrm{E}$, and $\mathrm{H}$ as adjunctive remedial. Trop. Anim. Health Prod. 44, 43-48.

Snecdecor, G.W., Cochran, W.G., 1994. Statistical methods, New Delhi, Iowa State University press, Ames, Oxford and IBH. 1994; pp 215-237.

Soulsby, E.J.L., 1982. Helminths, arthropods and protozoa of domesticated animals, 7th ed. Lea \& Febigerr, London.p.809.

Syed Mohmad, S., Manmohan Singh, C., 2017.
Reproduction in Buffalo Natural and Assisted reproductive techniques. Notion Press, Chennai. p. 216.

Tahan G, Aytac E, Aytekin H et al., (2011) Vitamin $E$ has a dual effect of antiinflammatory and antioxidant activities in acetic acid induced ulcerative colitis in rats. Can J Surg 54(5): 333-338.

Taylor, M.A., Coop, R.L., Wall, R.L., 2016. Veterinary Parasitology, 7th ed. Wiley. https://doi.org.10.1002/9781119073680

Tentori, L., Salvati, A.M., 1981. Hemoglobinometry in human blood, in: Methods in Enzymology. Elsevier, pp. 707715.

Veneziano, V., Neglia, G., Cimmino, R., Balestrieri, A., Rufrano, D., Bastianetto, E., Santoro, M., Gokbulut, C., 2013. The efficacy and safety of alphacypermethrin as a pour-on treatment for water buffalo (Bubalus bubalis) infested with Haematopinus tuberculatus (Phthiraptera: Haematopinidae). Parasitol. Res. 112, 2907-2912.

Veneziano, V., Rinaldi, L., Giannetto, S., Cringoli, G., 2003. The first record of Haematopinus tuberculatus on Bubalus bubalis (water buffalo) in Italy. Bubalus bubalis 9, 69-75.

Yoo, J.-H., Maeng, H.-Y., Sun, Y.-K., Kim, Y.A., Park, D.-W., Park, T.S., Lee, S.T., Choi, J.-R., 2009. Oxidative status in irondeficiency anaemia. J. Clin. Lab. Anal. 23, 319-323.

Zheltova, A.A., Kharitonova, M. V, Iezhitsa, I.N., Spasov, A.A., 2016. Magnesium deficiency and oxidative stress: an update. BioMedicine 6.

\section{How to cite this article:}

Madhesh, E., Umesh Dimri, Y. Ajith, S. Shanmuganathan, P. Sivasankar, R. Karthikeyan, Alok Kumar Choudhary and Kavitha, K. 2019. Vitamin E Ameliorates the Mineralo-Oxidative Stress of Sucking Lice Infestation in Indian Water Buffalo. Int.J.Curr.Microbiol.App.Sci. 8(07): 1538-1548. doi: https://doi.org/10.20546/ijcmas.2019.807.183 